\title{
Pengembangan e-modul sebagai Sumber Belajar Mata Pelajaran Bahasa Indonesia Kelas X MAN 1 Lombok Tengah
}

\author{
${ }^{1 *}$ Farida Fitriani, ${ }^{2}$ I. Indriaturrahmi \\ ${ }^{1}$ Program Studi Teknologi Pendidikan, FIPP, UNDIKMA, Jl. Pemuda No. 59A, Mataram, Indonesia \\ 83125 \\ 2Program Studi Pendidikan Tekologi Informasi, FSTT, UNDIKMA, Jl. Pemuda No. 59A, Mataram, \\ Indonesia 83125 . \\ *Corresponding Author e-mail: faridaa.fitrianii@gmail.com
}

Received: December 2019; Revised: February 2020; Published: March 2020

\begin{abstract}
Abstrak
Penelitian ini bertujuan untuk merancang bangun e-modul, mengembangkan serta menguji kelayakan e-modul mata pelajaran bahasa Indonesia. Penelitian ini dilakukan di MAN 1 Lombok Tengah dengan subjek penelitian sebanyak 32 orang kelas 10 semester I. Metode penelitian yang digunakan adalah penelitian dan pengembangan dengan model ADDIE (Analysis, Design, Development, Implementation And Evaluation). Uji kelayakan e-modul dilakukan oleh 2 orang ahli (1 ahli materi dan 1 ahli media) dan siswa. Ahli media menguji kelayakan aplikasi e-modul dan ahli materi menguji kedalaman materi bahasa indonesia, sedangkan siswa memberikan respon setelah menggunakan e-modul. Berdasarkan hasil uji kelayaakan maka diperoleh bahwa ahli media dan ahli materi menyatakan e-modul layak digunakan (ahli media $=87,5 \%$ dan ahli materi $=96,31 \%$ ), sedangkan siswa merespon positif $(87,7 \%)$. Berdasarkan hasil tersebut dapat disimpulkan bahwa e-modul mata pelajaran Bahasa Indonesia yang dikembangkan sangat layak sebagai sumber belajar untuk diterapkan pada siswa.
\end{abstract}

Kata Kunci: Sumber belajar, e-modul, Bahasa Indonesia

\section{Development of e-modules as Learning Resources for Indonesian Language Subjects Class X MAN 1 Central Lombok}

\begin{abstract}
This research aims to design e-modules, develop and test the feasibility of e-modules for Indonesian subjects. This research was conducted in MAN 1 Central Lombok with 32 class 10 semester I research subjects. The research method used was research and development with the ADDIE model (Analysis, Design, Development, Implementation and Evaluation). The e-module feasibility test was conducted by 2 experts (1 material expert and 1 media expert) and students. Media experts test the appropriateness of e-module applications and material experts test the depth of Indonesian language material, while students respond after using e-modules. Based on the results of the feasibility test, it was found that the media expert and material expert stated that the e-module was appropriate (media expert $=87.5 \%$ and material expert $=96.31 \%$ ), while students responded positively $(87.7 \%)$. Based on these results it can be concluded that the e-module of Indonesian subjects developed is very feasible as a learning resource to be applied to students.
\end{abstract}

Keywords: Learning Resources, e-module, Indonesian languages

How to Cite: Fitriani, F., \& Indriaturrahmi, I. (2020). Pengembangan e-modul sebagai Sumber Belajar Mata Pelajaran Bahasa Indonesia Kelas X MAN 1 Lombok Tengah. Jurnal Penelitian dan Pengkajian Ilmu Pendidikan: e-Saintika, 4(1), 16-25. doi:https://doi.org/10.36312/e-saintika.v4i1.165 


\section{PENDAHULUAN}

Guru sebagai tiang utama dalam proses pembelajaran harus mampu menyampaikan pengetahuan kepada siswa, bertujuan untuk meningkatkan kemampuan kognitif, efektif dan keterampilan siswa. Proses pembelajaran yang dilakukan oleh guru di Sekolah, merupakan suatu proses atau cara pendidik dalam mendistribusikan, menyampikan pengetahuan kepada siswa (Hamalik, 2013). Berbagai sumber belajar yang dimanfaatkan oleh guru dalam proses pembelajaran digunakan merupakan sumber infomrasi untuk mendukung keefektifan belajar siswa. Sumber belajar yang digunakan oleh guru sangat beragam seperti diktat, modul, alat peraga dan lain sebagainya. Sumber belajar merupakan kebutuhan penting sebagai sumber infomasi, sumber alat, sumber peraga serta berbagai kebutuhan yang diperlukan dalam menunjang pembelajaran (Musfiqon, 2012). Guru selain mengajar juga dituntut untuk mampu menganalisis kebutuhan, merancang, mendesain, menemukan, memprodukkan, dan menggunakan berbagai jenis sumber belajar. Modul adalah salah satu sumber belajar yang sering digunakan oleh guru, sebagai sarana pembelajaran dan pengajaran yang berisi pedoman pembelajaran, berupa materi, metode dan latihan soal serta evaluasi pembelajaran. Modul tersebut dikembangkan secara sistematis, bertujuan untuk mencapai kompetensi yang diharapkan oleh peserta didik serta dapat digunakan secara mandiri (Hamdani, 2011). Modul pembelajaran yang digunakan di sekolah masih bersifat konvensional. Kendala yang sering dijumpai saat menggunakan modul konvensional antara lain siswa cepat merasa bosan dan kurang tertarik mempelajari materi yang terdapat pada modul, hal ini biasanya berpengaruh pada hasil belajar siswa. Kurang efisien karena siswa harus mengeluarkan biaya lebih untuk memperbanyak modul. Disamping itu, saat ini pengguna teknologi smart phone meningkat pesat tak luput juga para siswa setiap harinya bermain gadget, tentunya hal ini menjadi motivasi bagi guru untuk berinovasi dalam mengembangkan pembelajaran berbasis teknologi yang sesuai tuntutan zaman. untuk mengantisipasi hal-hal yang kurang positif seperti siswa lebih banyak menghabiskan waktu bermain media sosial atau game online. Hal tersebut sejalan dengan yang dikatakan oleh oleh Syafrudin (2019) potensi sarana di sekolah belum di manfaatkan dengan baik, pemanfaatan sarana belajar yang rendah, sehingga motivasi dan minat belajar siswa dalam mengatasi permasalahan belajar rendah.

Berdasarkan kondisi tersebut pengembangan modul dengan memanfaatkan teknologi informasi dikembangakan menjadi e-modul. E-modul merupakan modul digital non-cetak yang dikembangakan dengan aplikasi khusus dan dengan berbantuan komputer, serta diberikan elemen multimedia untuk lebih menarik dan interaktif. Fitriani (2019) juga menjelaskan tentang perbedaan modul cetak dengan emodul adalah modul cetak menggunakan kertas sedangkan e-modul merupakan modul elektronik yang pengembangkan dan pengaplikasiannya memanfaatkan teknologi informasi. Melalui e-modul ini diharapkan dapat memberikan kemudahan kepada guru untuk memfasilitasi siswa yang memiliki karakteristik belajar dengan kecepatan belajar yang berbeda-beda. Pengembangan e-modul disesuaikan dengan karakteristik dan kebutuhan pengguna (user), bertujuan untuk menarik minat siswa dalam menggunakan e-modul dan untuk mencapai kompetensi pembelajaan yang diharapkan. e-modul digunakan sebagai alat atau sarana pembelajaran yang berisi materi, metode, batasan-batasan dan cara mengevaluasi (Wibowo, 2018). Sejalan dengan itu, manfaat pengembangan e-modul ini dapat mengkondisikan kegiatan 
pembelajaran di kelas lebih terencana dengan baik, mandiri, tuntas dan output yang jelas. Selain itu, melalui bahan ajar (modul) guru akan lebih mudah dalam

Tujuan dari penelitian ini untuk mengembangakan e-modul sebagai sumber belajar mata pelajaran bahasa Indonesia. Selama ini modul yang biasa digunakan oleh siswa adalah modul konvensional atau modul cetak, modul tersebut dirasa kurang efektif apalagi ditengah berkembangnya teknologi informasi yang semakin canggih. Oleh sebab itu, diperlukan suatu inovasi dalam pembelajaran dengan memanfaatkan teknologi yaitu pengembangan modul berbasis digital atau e-modul. Dengan dikembangkannya e-modul dapat menjadi alternative sumber belajar bagi siswa yang memberikan kemudahan untuk dapat belajar dengan memanfaatkan laptop atau komputer bahkan gadget, tanpa harus mengelurkan biaya lebih untuk memberbanyak modul, serta belajar dapat dilakukan kapan pun dan dimanapun.

\section{METODE}

Penelitian ini bertujuan untuk mengembangkan e-modul bahasa Indonesia sebagai sumber belajar siswa. Metode yang sesuai digunakan dalam penelitian ini adalah metode penelitian dan pengembangan (Research and Development) dengan pendekatan ADDIE. Menurut Sugiyono (2015), Penelitian dan pengembangan atau dalam bahasa Inggris Research and Development (R\&D) adalah serangkain proses ilmiah untuk meneliti, merancang, memproduksi dan menguji validitas produk yang telah dikembangkan atau dihasilkan. Sedangkan ADDIE merupakan inisial dari Analysis, Design, Development or Production, Implementation or Delivery and Evaluation dikembangkan oleh Dick and Carry (1996) dalam Mulyatiningish (2016). Menurut Usta dan Guentepe (2017) kelebihan model ADDIE adalah sederhana, mudah dipahami dan dan memiliki struktur yang dapat memfasilitasi metode pengajaran yang berfokus pada pelajar. Pendekatan ADDIE digunakan dalan mengerjakan urutan langkah penelitian dan pengembangan yang terdiri dari 5 tahapan seperti pada Gambar 1 berikut.

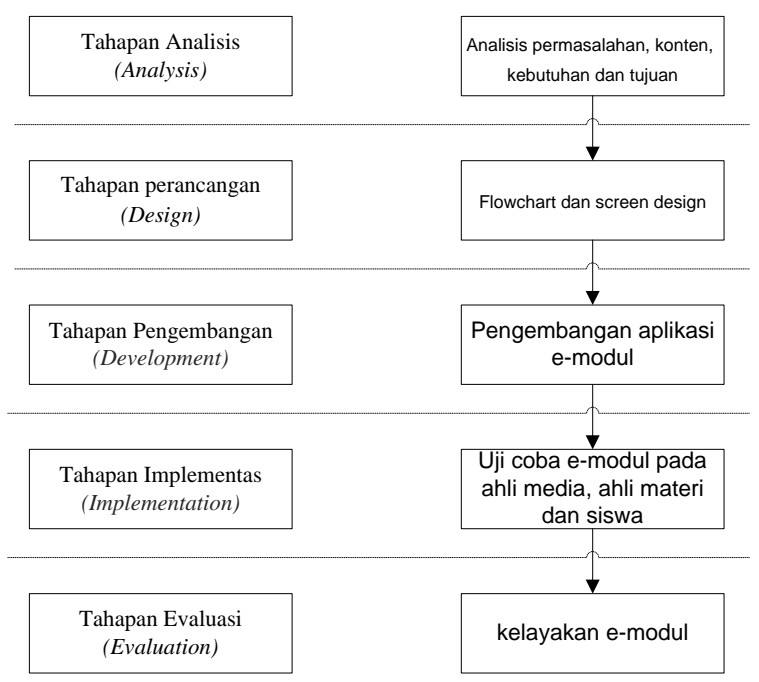

Gambar 1 Tahapan Penelitian ADDIE

Penelitian ini dilaksanakan pada Madrasah Aliyah Negeri (MAN) 1 Lombok Tengah Tahun Ajaran 2019/2020, pada Kelas X semester I yang terdiri atas 32 siswa. Instrumen uji kelayakan berupa angket yang digunakan untuk mengukur kelayakan e-modul Bahasa Indonesia. Instrumen uji kelayakan berupa isi, kebahasaan, penyajian 
dan kemanfaatan. Instrumen tersebut diberikan kepada ahli materi yaitu guru bidang studi mata pelajaran Bahasa Indonesia kelas $X$ dan ahli media bidang Teknologi Pendidikan berupa isi, tampilan modul elektronik, kemudahan penggunaan, konsistensi, dan aspek kegrafikan, serta pada pengguna yaitu siswa. Aturan pemberian skor pertanyaan menggunakan skala linkert 4 point dengan rentan skor minimal 1 hingga skor maksimal bernilai 4 . Berikut Tabel 1 penilaian kuesioner skala lingkert.

Tabel 1 Penilain kuesioner skala lingkert

\begin{tabular}{lr}
\hline Keterangan & Skor \\
\hline Sangat Setuju (SS) & 4 \\
Setuju (S) & 3 \\
Tidak Setuju (TS) & 2 \\
Sangat Tidak Setuju (STS) & 1 \\
\hline
\end{tabular}

Teknik analisis data yang digunakan adalah teknik analisis data kuantitatif dan kualitatif. Teknik ini bertujuan untuk memaparkan hasil pengembangan produk setelah diimplementasikan dan diuji kelayakan produk (Khoirot, 2016). Data nilai kuantitatif yang diperoleh dari hasil pengujian pada ahli media dan materi serta siswa akan dibuat menjadi data kualitatif. Hasil perhitungan skor uji kelayakan e-modul digunakan untuk menyimpulkan tingkat kelayakan e-modul berdasarkan pada komponen yang diteliti menggunakan persamaan berikut.

$$
\text { Presentasi kelayakan } \%=\frac{\text { skor yang diobsesrvasi }}{\text { skor yang diharapkan }} \times 100 \%
$$

Data kuantitatif hasil perhitungan skor presentasi kelayakan, selanjutnya diubah menjadi data kulaitatif, hal tersebut digunakan untuk menyimpulkan tingkat pencapain dari kelayakan media. Menurut Sugiyono (2015) hasil skala rating setelah diubah menjadi presentasi rerata kemudian ditafsirkan kedalam bentuk kualitatif. Tabel 2 kategori kelayakan berdasarkan skala rating sebagai berikut.

Tabel 2 Kategori kelayakan

\begin{tabular}{cc}
\hline Interval $(\%)$ & Kriteria \\
\hline $76-100$ & Sangat layak \\
$51-75$ & Cukup Layak \\
$26-50$ & Tidak Layak \\
$0-25$ & Sangat Tidak Layak
\end{tabular}

(Fetriani, 2018)

\section{HASIL DAN PEMBAHASAN}

Pengembangan e-modul singkatan dari elektronik modul sebagai sumber mata pelajaran Bahasa Indonesia sebagai alternatif metode belajar dengan memanfaatkan teknologi. Modul itu sendiri berupa sebuah buku atau diktat, dikemas sedemikan rupa berisi materi atau komponen bahan ajar hingga evaluasi yang dapat digunakan secara mandiri oleh peserta didik tanpa bimbingan guru (Majid, 2013). Modul yang selama ini digunakan berupa buku atau diktat yang dicetak dan didistribusikan secara manual disebut modul konvensional. Sedangkan e-modul merupakan bahan ajar atau media ajar yang memanfatkan teknologi informasi. Modul dengan e-modul memiliki bentuk yang berbeda dalam menyajikan bahan atau materi ajar, e-modul 
disusun secara sistematis dan terstruktur, dilengkapi dengan usur multimedia (animasi, audio, suara, navigasi) yang membuat materi dalam e-modul lebih menarik dan interaktif bagi peserta didik guna mencapai tujuan pembelajaran (Prayuda, 2017).

Tujuan pengembangan e-modul adalah untuk meningkatkan kualitas sumber belajar yang ada di sekolah, meningkatkan kemandirian siswa serta memberkan inovasi dalam pembelajaran dengan menambah media bagi guru dalam melakukan kegiatan pembelajaran di kelas (Putra, Wirawan \& Pradnyana, 2017). Menurut Nyoman dan Jayanta (2017) letak perbedaan e-modul dengan modul konvensional antara lain: (1) e-modul lebih interaktif dan memiliki fitur navigasi sehingga memberikan kemudahan, (2) materi bahan ajar disajikan dan ditampilkan dalam bentuk animasi, video, suara video, dan animasi , (3) dilengkapi dengan evaluasi berupa kuis atau tes formatif yang memungkinkan dapat langsung memberikan umpan balik secara realtime.

Pengembagan e-modul mata pelajaran Bahasa Indonesia menggunakan model ADDIE yang terdiri dari 5 tahapan (Analyze, Design, Development, Implementation dan Evaluation). Tahapan pertama Analyze, tahapan ini lebih banyak melakukan analisis segala kebutuhan yang akan digunakan dalam pengembangan aplikasi e-modul seperti (1) analisis permasalahan yang menjadi landasan pengembangan e-modul. (2) analisis konten, berupa mata pelajaran dan karakterisik siswa (3) analisis kebutuhan baik kebutuhan perangkat keras dan perangkat lunak pendukung aplikasi e-modul. Tahapan kedua Design, tahapan ini dilakukan berdasarkan hasil dari analisis yang telah dilakukan. Menghasilkan desain pengembangan e-modul (Gambar 2) yaitu screen design merupakan rancangan desain antarmuka dari e-modul dan flowchart meruapkan desain sistem dari alur penggunan e-modul.

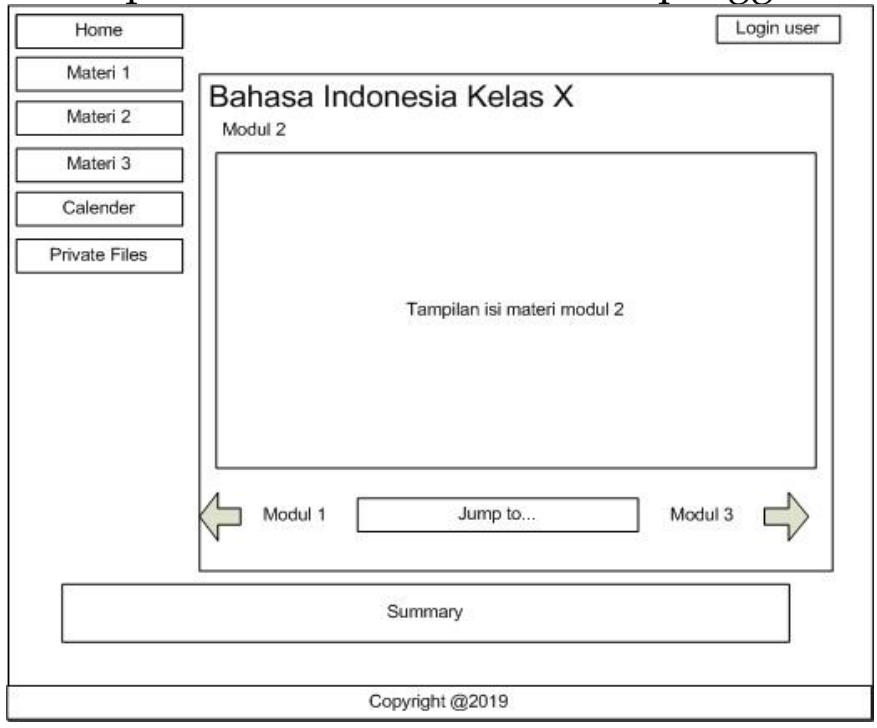

Gambar 2. Rancangan desain antar muka e-modul

Pada Gambar 2 merupakan rancangan desain antarmuka aplikasi e-modul mata pelajaran bahasa Indonesia yang akan dikembangkan dalam bentuk visual. rancangan desain antar muka tersebut berisi tombol menu home, materi 1, materi 2 dan dst, serta calendar dan private files. Setiap materi yang diklik oleh pengguna ditayangkan pada sisi tengah. Hal tersebut untuk memudahkan penggunan untuk membaca isi modul, disamping itu terdapat tombol pada sisi kiri dan kanan sebagai navigasi untuk melanjutkan atau mengulang materi pada modul. Pada Gambar 3 menggambarkan urutan dan hubungan proses dalam aplikasi e-modul mata 
pelajaran bahasa Indonesia. Flowchart tersebut memperllihatkan alur kerja pengguna (admin, user dan guru) dalam menggunakan e-modul.

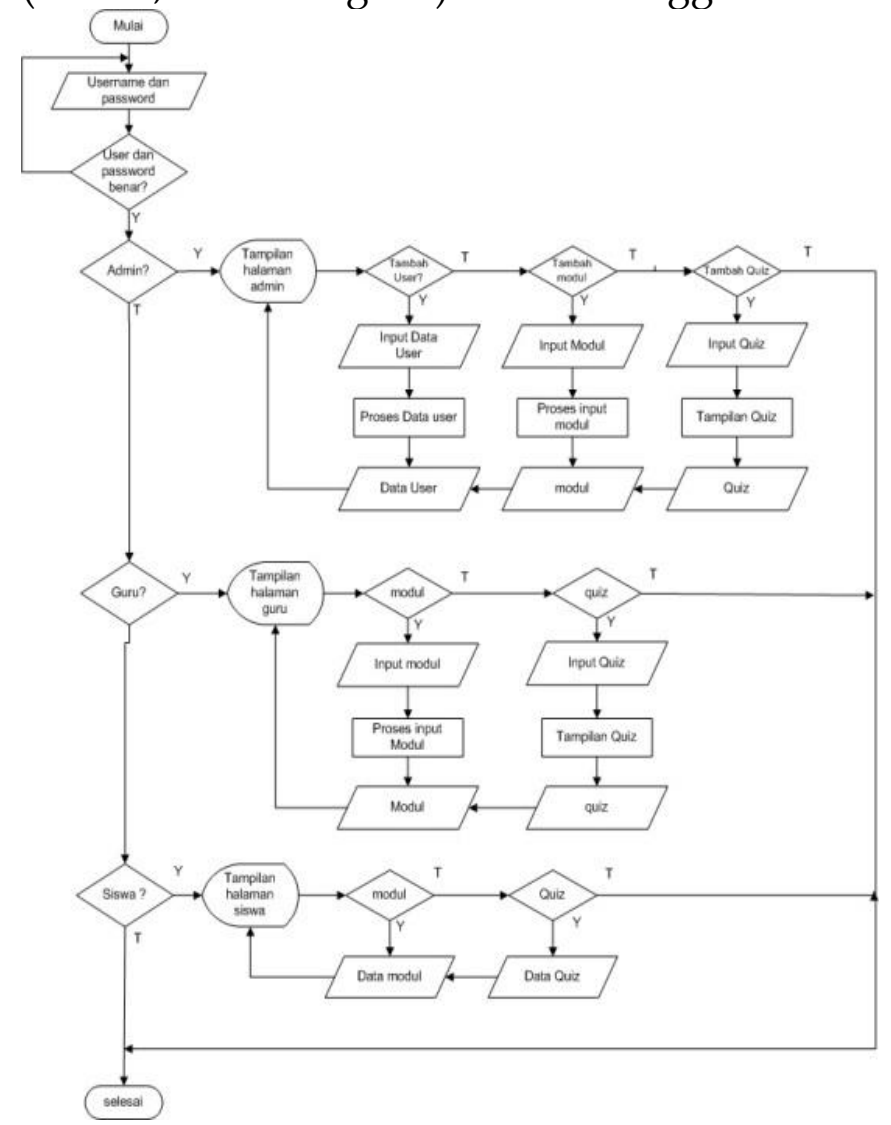

Gambar 3. Flowchart program e-modul

Tahapan ketiga Development, tahapan ini dilakukan proses pengembangan emodul meliputi membuat desain antar muka berdasarkan rancangan struktur yang telah dibuat, pengemabangan fitur yang meliputi isi modul, materi dan quiz serta pemberian hak akses pada penggunan guru dan siswa agar dapat mengakses e-modul serta terakhir menghasilkan sebuah aplikasi e-modul mata pelajaran bahasa Indonesia. Pada Gambar 4 disajikan halaman e-modul mata pelajaran bahasa Indonesia yang telah selesai dikembangkan.

\section{ê-modul.id}

Bahasa Indonesia Kelas X
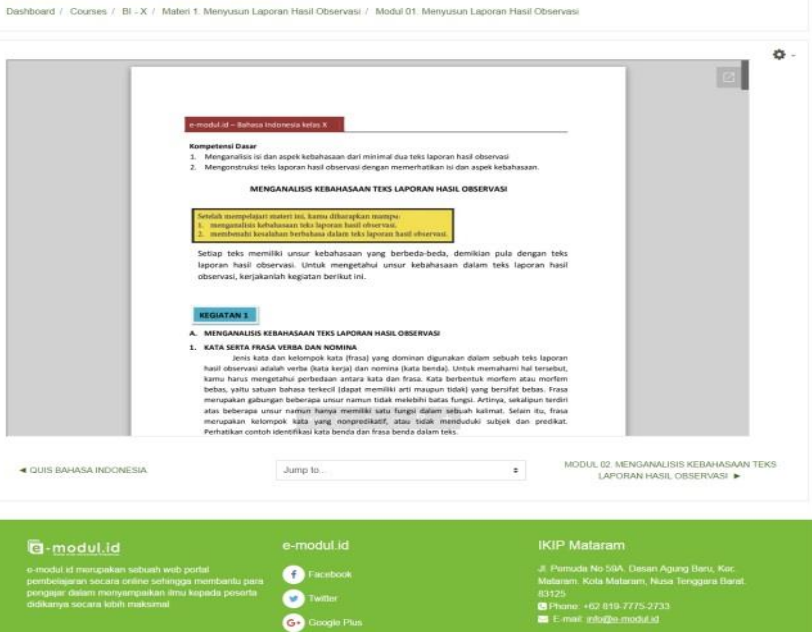

Gambar 4. Tampilan e-modul bahasa Indonesia 
Tahapan Implementation, tahapan ini dilakuakn uji kelayakan aplikasi e-modul pada para ahli dan pengguna (siswa), sebelum diimplementasikan pada pengguna sebeneranya. Pengujian dilakukan oleh ahli media, ahli materi dan siswa yang bertujuan untuk memastikan bahwa e-modul ini dapat berjalan dengan baik, materi yang diberikan sesuai dengan kurikulum yang diajarkan serta siswa dapat menggunakn e-modul dengan mudah. Berdasarkan uji kelayakan yang telah dilakukan berikut hasil perhitungan kuesioner yang diperoleh.

\section{Uji kelayakan pada ahli media}

Kuesioner penilaian yang diberikan pada ahli media untuk menguji kelayakan e-modul dari sisi media sebanyak 25 butir pertanyaan, yang terdiri dari dari 4 kompoen pertanyaan yang mencakup tampilan e-modul, desain antarmuka, navigasi dan pengalaman pengguna. Rata-rata skor yang didapatkan setiap komponen pertanyaan seperti pada Tabel 3 berikut,

Tabel 3 skor penilaian ahli media

\begin{tabular}{lll}
\hline Komponen penilaian & Rata-rata skor & Kriteria \\
\hline Tampilan & $92,85 \%$ & Sangat Layak \\
Desain Antarmuka & $96,42 \%$ & Sangat Layak \\
Navigasi & $100 \%$ & Sangat Layak \\
Pengalaman Pengguna & $96 \% \%$ & Sangat Layak \\
Total skor & $96,31 \%$ & Sangat Layak \\
\hline
\end{tabular}

\section{Uji kelayakan pada ahli materi}

Pada uji kelayakan e-modul oleh ahli materi. Pertanyaan kuesinoer sebanyak 25 butir pertanyaan yang mencakup 4 kompoenen penilain yaitu komponen kelayakan materi, penyajian, navigasi dan pengalaman pengguna. Rat-rata skor yang didapatkan pada setiap komponen pertanyaan dapat dilihat pada Tabel 4 skor penilaian ahli materi berikut.

Tabel 4 skor penilaian ahli materi

\begin{tabular}{lll}
\hline Komponen Penilaian & Rata-rata Skor & Kriteria \\
\hline Kelayakan Materi & $87,5 \%$ & Sangat layak \\
Penyajian & $87,5 \%$ & Sangat layak \\
Navigasi & $75 \%$ & Cukup layak \\
Pengalaman Pengguna & $100 \%$ & Sangat layak \\
Total skor & $87,5 \%$ & Sangat layak \\
\hline
\end{tabular}

\section{Uji kelayakan pada siswa}

Penilaian uji kelayakan e-modul Bahasa Indonesia melibatkan 32 orang siswa. Setiap siswa diminta untuk mempraktikkan e-modul Bahasa Indonesia, setelah itu diberikan kuesioner uji kelayakan yang terdiri dari 25 butir pertanyaan. Kuesioner tersebut dibagi menjadi 5 komponen penilaian yaitu komponen isi, tampilan, navigasi, kebahasaan, pengalaman pengguna. Berikut rata-rata hasil penilaian setiap komponen seperti disajikan pada Tabel 5.

Tabel 5. Skor penilaian siswa

\begin{tabular}{lll}
\hline Komponen Penilaian & Rata-rata Skor & Kriteria \\
\hline Kelayakan Isi & $88 \%$ & Sangat layak \\
Tampilan & $88 \%$ & Sangat layak \\
\hline
\end{tabular}




\begin{tabular}{lll}
\hline Komponen Penilaian & Rata-rata Skor & Kriteria \\
\hline Navigasi & $90 \%$ & Sangat layak \\
Kebahasaan & $89 \%$ & Sangat layak \\
Pengalaman Pengguna & $84 \%$ & Sangat layak \\
Total Skor & $87,7 \%$ & Sangat layak \\
\hline
\end{tabular}

Produk pengembangan e-modul yang telah dikembangkan sebagai sumber mata pelajaran bahasa Indonesia dapat diaskes secara online. Materi pelajaran bahasa Indonesia yang disajikan ditujukan untuk siswa, dikemas dalam bentuk modul digital yang dapat diakses melalui komputer ataupun mobile phone masing-masing siswa. Hasil penelitian pengembangan e-modul mata pelajaran bahasa indonesia sejalan dengan hasil penelitian yang dilakukan oleh Putra et al., (2017) dengan judul pengembangan e-modul berbasis model pembelajaran discovey learning pada mata pelajaran sistem komputer untuk siswa kelas X Multimedia SMKN 3 Singaraja. Hasil uji kelayakan yang dilakukan pada ahli desain pembelajaran, isi, media serta uji coba perorangan, uji coba kelompok dan lapangan termasuk dalam kategori baik dan mendapatkan respon positif. Sehingga layak digunakan sebagai sumber belajar untuk siswa kelas X Multimedia di SMKN 3 Singaraja. Penelitian terkait lainnya yang dilaukan oleh Pradana et all,. 2019 dengan judul pengembangan e-modul berbasis mobile learning mata pelajaran seni budaya konsep budaya, seni dan keindahan kelas X SMKN 1 Turen Malang. Hasil uji validasi yang dilakukan pada ahli media, ahli materi dan siswa diperolah ahli media sebesar $98,75 \%$, ahli materi sebesar $96,35 \%$ dan siswa sebesar $89,25 \%$ berdasarkan hasil tersebut penelitian tersebut dinyatakan valid dan layak untuk digunakan dalam pembelajaran.

Pemanfaatan e-modul dalam pembelajaran telah banyak digunakan oleh guru di sekolah untuk menunjang pembelajaran pada siswa. Dari pembahasan penelitain di atas hasil pengujian e-modul yang dilakukan oleh ahli materi, ahli media dan audience (siswa) secara garis besar mendapatkan respon positif dan hasil yang baik. Hal tersebut selaras dengan hasil penelitian Pengembagnan E-Modul Sebagai Sumber Belajar Mata Pelajaran Bahasa Indonesia Kelas X MAN 1 Lombok Tengah. Berdasarkan hasil uji kelayaan yang telah dilakuka, rata-rata penilaian yang diperoleh dari ahli media sebesar 87,5\% dari ahli materi sebesar 96,31\% dan uji kelayakan pada siswa didapat sebesar $87,7 \%$ maka berdasarkan kategori kelayakan e-modul mata pelajaran Bahasa Indonesia sebagai sumber belajar sangat layak untuk diterapkan pada siswa.

\section{KESIMPULAN}

E-modul mata pelajaran Bahasa Indonesia sebagai sumber belajar bahasa indonesia telah dikembangkan dan dapat diakses pada laman http://e-modul.id/. Pengembangan e-modul berdasarkan kebutuhan dari pengguna yaitu siswa dan sesuai dengan materi yang akan diajarkan oleh guru. Isi ata materi dalam e-modul disesuaikan dengan kurikulum yang sedang digunakan saat itu. Pada e-modul siswa diberkan hak akses untuk mengakses materi yang dikemas secara menarik dengan memberikan usur multimedia didalamnya serta evaluasi berupa latihan dan quiz berbasis online. siswa dapat belajar secara mandiri kapan pun dan dimanapun. Guru juga dapat memantu aktivitas belajar siswa secara realtime. Berdasarkan hasil uji kelayakan yang telah dilakukan, implementasi e-modul mata pelajaran bahasa indonesia sebagai sumber belajar siswa di MAN 1 Lombok Tengah telah berhasil 
dikembangkan dan layak untuk diterapkan, dilihat dari prosentasi hasil uji kalayakan dari ahli media media sebesar $87,5 \%$ dari ahli materi sebesar $96,31 \%$ dan uji kelayakan pada siswa didapat sebesar $87,7 \%$.

\section{SARAN}

Dalam mengembangkan e-modul hal-hal yang perlu diperhatikan analisis kebutuhan user, hardware dan software. Pada kebutuhan pengguna, disini peneliti menggali seperti apa permasalahan yang dihadapi oleh user, karena setiap aplikasi yang akan dikembangkan akan menyesuaikan kebutuhan dari pengguna yang akan menggunakan aplikasi tersebut. kebutuhan software, setelah menganalisis kebutuhan user, setelah itu peneliti perlu mencari software apa yang akan digunakan untuk mengembangakan e-modul, tentunya aplikasi yang dikembangkan dapat user friendly dan terakhir kebutuhan hardware, kebutuhan hardware untuk mengembangakan dan kebutuhan hardware dari user. Agar aplikasi e-modul yang dikembangkan dapat berjalan di laptop atau PC serta agar mudah digunakan oleh user.

\section{UCAPAN TERIMA KASIH}

Penulis mengucapkan ucapan terima kasih yang sebesar-besarnya pada DP2M DIKTI yang telah membiayai riset penulis melalui skim peneliti dosen pemula (PDP) Tahun 2019 dengan Kontrak No; 0823/L8/KM/ 2019.

\section{DAFTAR PUSTAKA}

Fetriani, A. (2018). Pengembangan E-Modul Adobe Premiere Sebagai Bahan Ajar Mata Pelajaran Sinematografi Kelas Xi Multimedia SMK Muhammadiyah 1 Sleman. Skripsi. Universitas Negeri Yogyakarta

Fitriani,F., \& Indriaturrahmi. (2019). Analisis dan Perancangan Sistem Pengembangan EModul Mata Pelajaran Bahasa Indonesia. Prosiding Seminar Nasional (126-135), Mataram, Indonesia: Fakultas Ilmu Pendidikan, IKIP Mataram.

Hamalik, O. (2013). Proses Belajar Mengajar. Jakarta : PT.Bumi Aksara

Hamdani. (2011). Strategi Belajar Mengajar. Bandung : Pustaka Setia.

Khoirot, T. (2016). Pengembangan Dan Uji Kelayakan Modul Pembelajaran Microsoft Access 2010 Sebagai Bahan Ajar Keterampilan Komputer Dan Pengelolaan Informasi Untuk Kelas Xi SMK Negeri Bansari. E-JPTI Vol 5, No. 72016 hal: 1-6

Lee, W. W., \& Owens, D. L. (2004). Multimedia-based instructional design: computer-based training, web-based training, distance broadcast training, performance-based solutions. California: Pfeiffer

Majid, A. (2013). Perencanaan Pembelajaran . Bandung: PT Remaja Rosdakarya

Musfiqon. (2012). Pengembangan Media dan Sumber Pembelajaran. Jakarta: Prestasi Pustakakarya.

Pradana, S \& Husna, A. (2019). Pengembangan E-Modul Berbasis Mobile Learning Mata Pelajaran Seni Budaya Konsep Budaya, Seni, Dan Keindahan Kelas X SMKN 1 Turen Malang. JINOTEP, 6(2), 89-96.

Prayudha, D R. (2016). Pengembangan E Modul dengan Model Prolem Based Learning Pada Materi Bilangan Buat Kelas VII. Aksioma: Jurnal Matematika dan Pendidikan Matematika. 7(1), 48-56

Putra, I,. M., A., W \& Pradnyana, G., A. (2019). Pengembangan E-Modul Berbasis Model Pembelajaran Discovery Learning Pada Mata Pelajaran Sistem Komputer 
Untuk Siswa Kelas X Multimedia SMK Negeri 3 Singaraja. Jurnal Pendidikan Teknologi dan Kejuruan, 14(1), 40-59

Sugiyono. (2015). Metode Penelitian E Pengembangan (Research and Development/RED). Bandung: Alfabeta.

Solikin, I. (2018). Implementasi E-Modul pada Program Studi Manajemen Informatika Universitas Bina Darma Berbasis Web Mobile. Jurnal Resti (Rekayasa Siste dan Teknologi Inormasi), 2(2), 492-497.

Usta, N, D. \& Guetepe, E.T. (2017). Pre-Service Teachers' Material Development Process Based on the ADDIE Model: E-book Design. Journal of Education and Tranining Studies. 5(12), 199-210.

Wibowo, E. (2018). Pengembangan Bahan Ajar E-Modul dengan Menggunakan Aplikasi Kvisoft Flipbook Maker. Skripsi. Fakultas Tarbiyah dan Keguruan Universitas Islam Negeri Raden Intan Lampung. 